\title{
Ankara İli Ayaş ve Nalıhan İlçelerinde Domates Üretim Alanlarında Zirai Mücadele Uygulamaları
}

\author{
Fikret DEMiRCi ${ }^{1}$
}

Cem ERDOĞAN ${ }^{2}$

F. Füsun TATLIDIL ${ }^{3}$

Geliş Tarihi: 20.09.2005

\begin{abstract}
Öz: Bu çalışma, Ankara ili Ayaş ve Nallıhan ilçeleri domates ekiliş alanlarında üreticilerin yürütmekte olduğu zirai mücadele çalışmalarının yerinde izlenmesi, uygulama hatalarının belirlenmesi amacı ile 2000 ve 2001 yıllarında yürütülmüştür. Gerek yapılan gözlemler, gerekse yapılan anket çalışmaları ile çiftçilerin domates fideliklerinde ve tarla koşullarında karşılaştıkları problemler belirlenmiştir. Yapılan zirai mücadele uygulamalarına rağmen, Ayaş ilçesinde toplam \%25.92, Nallıhan ilçesinde ise toplam \%27.51 oranında ürün kaybı olduğu, ve bu kayıpların büyük bir çoğunluğunun fide döneminde meydana geldiği belirlenmiştir. Çiftçilerin hatalı zirai mücadele uygulamaları üzerinde durulmuş olup, bunlara ait çözüm önerilerine yer verilmiştir.
\end{abstract}

Anahtar Kelimeler: Domates, ürün kaybı, hastalık ve zararılır

\section{Plant Protection Practices in Tomato Plantations in Ayaş and Nallıhan Provinces of Ankara}

\begin{abstract}
The study was conducted to observe agricultural practices of the farmers and to define the errors in the plant protection applications in tomato growing areas of Ayaş and Nallıhan provinces of Ankara in 2000 and 2001. The problems that the farmers had in the nurseries and the field were determined by both the observations and the questionnaires. In spite of the farmers' plant protection practices, it was determined that, the yield losses reached to $25.92 \%$ in Ayass, and $27.51 \%$ in Nallıhan provinces totally. It also determined that, the majorities of the yield loses were arise from the nurseries. In this study, the farmers' misapplications and suggestions about the solutions were emphasized in this paper.
\end{abstract}

Key Words: Tomatoes, yield loss, pests and diseases

\section{Giriş}

Dünyada ve ülkemizde nüfusun hızla artması, tarımsal üretimin bu artışa karşılık verememesi günümüzde yetersiz ve dengesiz beslenme sorunlarını beraberinde getirmektedir. Aynı zamanda sanayi sektörüne uygun ve yeterli hammaddenin sağlanması ve dışsatım için yeterli ve kaliteli ürün elde edilebilmesi için tarımsal üretimde verimin arttırımasını amaçlayan çalışmalara büyük önem verilmektedir. Dünyada ve ülkemizde domates üretimi yapılan ve oldukça fazla tüketilen önemli sebzelerden biridir. Türkiye, dünya domates ekim alanlarının \%4.39'unu oluşturmakta ve dünyada ekim alanı bakımından 5. sırada bulunmaktadır Üretim bakımından ise \% 6.90'lık payla 4. sırada yer almaktadır. İhracat açışından ise 690 tonla İtalya'nın ardından 2. sırayı almaktadır (Anonymous 1999). Ülkemizde toplam sebze üretiminde \%26 ile en yüksek paya sahip olan domates, taze olarak tüketilmesinin yanı sıra konserve, salça ve domates suyu olarak da tüketilmektedir. Ankara ilinde Ayaş ve Nalıhan ilçelerinde domates üretimi yoğun olarak yapılmaktadır. Yoğun olarak domates üretilen bu bölgede üretim, toplama ve nakliye esnasında birçok kayıplar olmaktadır. Konunun ekonomik boyutu dikkate alındığında Fide yetiştirme döneminde dekara yapılan toplam masraf, Ayaş ilçesinde 32,59 YTL, Nallıhan ilçesinde 110,02 YTL olarak hesaplanmıştır. Ayaş ilçesinde bir adet fidenin maliyeti 4 yeni kuruş, Nallıhan ilçesinde 10 yeni kuruştur. Fide maliyetinde değişim tohum fiyatlarındaki farklılıktan ve Nallıhan ilçesinde dekara daha fazla tohum kullanılmasından ileri gelmektedir. Ayaş ilçesinde bodur, Nallıhan ilçesinde sırık domates çeşitleri yetiştirilmektedir. Tarla döneminde işletmelerde bir dekar domates yetiştiriciliği için yapılan toplam masraflar, Ayaş ilçesinde 280,49 YTL, Nallıhan ilçesinde 422,05 YTL'dir. Ayaş ilçesinde yer alan işletmelerde ortalama domates verimi $4.712 \mathrm{~kg} / \mathrm{da}$, Nallıhan ilçesinde $5.108 \mathrm{~kg} / \mathrm{da}$ 'dır. Araştırmanın yürütüldüğü ilçelerde bir $\mathrm{kg}$ domates maliyeti sırasıyla 6 yeni kuruş ve 8 yeni kuruştur.Birim alana elde edilen brüt ve net karlar dikkate alındığında, Ayaş ilçesinde domates yetiştiriciliğinde birim alana elde edilen brüt ve net karlar Nallıhan ilçesine göre daha yüksektir. Ayaş ilçesinde dekara elde edilen ortalama brüt ve net karlar sırasıyla 116,06 YTL ve 79,11 YTL, Nallıhan ilçesinde 98,53 YTL ve 65,91 YTL'dir (Tatıdil ve ark. 2003)

Bu çalışma TÜBiTAK' ın desteklemiş olduğu TARP-2387 no.' lu proje kapsamında yürütülmüştür.

${ }^{1}$ Ankara Üniv. Ziraat Fak. Bitki Koruma Bölümü-Ankara

${ }^{2}$ T.C. Tarım Bakanlığı Ankara Merkez Zirai Mücadele Araştırma Enstitüsü-Ankara

${ }^{3}$ Ankara Üniv. Ziraat Fak. Tarım Ekonomisi Bölümü -Ankara 

uygulamaları"

Ülkemizde domates hastalıkları ile ilgili ilk kayıtlara Bremer (1948) tarafından kaleme alınan "Türkiye Fitopatolojisi" adlı eserde rastlanılmaktadır. Ancak bu eserde bahsedilen domates hastalıklarının birçoğunun 'Türkiye' deki domates ekiliş alanlarından izole edilmediği görülmekte, ülkemizde $\mathrm{o}$ tarihlerde domates ekiliş alanlarında bulunması muhtemel hastalıklar ele alınmaktadır. Yine aynı araştırıcı daha sonraki yıllarda Türkiye domates ekiliş alanlarında görülen hastalıkların tespiti üzerine oldukça kapsamlı çalışmalar yürütmüş ve bu çalışmalarının sonuçlarını, kaleme aldığı Türkiye Fitopatolojisi eserinin Bahçe Kültürleri Hastalıkları cildinde yayınlamıştır. Halen günümüzde de sorun olan birçok viral, bakteriyel ve fungal hastalık etmenlerinin domateslerde zararlara neden olduğunu belirlemiştir (Bremer 1954) Karahan (1960, 1963), Gürcan (1968), Özalp ve Bağcı (1968), Dolar ve ark. (1976) Temiz ve Fesli (1978), Yücel (1989, 1994), Yücel ve Çınar (1989), Kahveci ve Gürcan (1993), Güldür ve Yılmaz (1995) ve Abak ve ark. (2000) nın domates hastalıklarını, Öngören ve ark. (1975), Toros (1976), Şengonca ve Yurdakul (1977), Erkuş ve ark. (1992), Tanrıvermiş (2000)'in domates zararlılarını ve sebze üretimi veya domateste ekonomik kayıpları konu alan araştırmaları mevcuttur.

Bu araştırma, Ankara ili, Ayaş ve Nalıhan ilçelerinde basit tesadüfi örnekleme yöntemine göre belirlenen işletmelerde üreticilerin yürütmekte olduğu zirai mücadele çalışmalarının yerinde izlenmesi, uygulama hatalarının ve eksikliklerinin belirlenmesi ve çözüm yollarının ortaya konması amacıyla yürütülmüştür.

\section{Materyal ve Yöntem}

Araştırmanın ana materyalini, Ayaş ve Nallıhan ilçelerinde domates yetiştiriciliğinin yoğun olarak yapıldığı köylerden seçilen işletmelerden elde edilen veriler oluşturmaktadır. Anket uygulanacak işletme sayısı basit tesadüf örnekleme sistemine göre yapılmıştır (Güneş ve Arıkan 1988). Domates yetiştiriciliği yapılan arazilerin genişliği dikkate alınarak uygulanan bu örnekleme sistemine göre, Ayaş ilçesinde 74, Nallıhan ilçesinde 34 örnek işletme belirlenmiş olup, fide ve tarla dönemlerindeki yetiştirme uygulamaları yerinde incelenmiştir. 2000 ve 2001 yıllarında gerek bizzat yörede yapılan gözlemlerle gerekse de mahallinde yapılan anketlerle elde edilen veriler değerlendirilmiştir.

Proje kapsamında, öncelikle Ayaş ve Nallıhan İlçe Tarım Müdürlüğü teknik elemanları ile karşılıklı olarak bilg alış verişinde bulunularak, domates yetiştiriciliğinin yoğun olarak yapıldığı köyler seçilmiş ve daha sonra bu köylere gidilerek örnek işletmeler belirlenmiştir. Bu esnada, henüz domates yetiştirme faaliyetleri başlamadığı için, üreticilerin geçmiş yıllarda yörede problem oluşturan hastalık ve zararlılar ile bunlara karşı yürüttükleri mücadele çalışmaları hakkında bilgi alınmıştır. Domates yetiştirme faaliyetlerinin başlaması ile birlikte üreticilerin yürüttükleri mücadele çalışmaları farklı zamanlarda işletmelere gidilerek yapılan gözlemlerle ve daha sonrada hazırlanan anketlerle belirlenmiştir. Bu gözlemlere, örtü altında fide üretim döneminden itibaren başlanarak, fidelerin tarlaya şaşırtılmasından hasat döneminin başlangıcı ve sonuna kadar devam edilmiştir. Üreticilere anket uygulaması bizzat mahallinde gerçekleştirilmiştir. Elde edilen veriler analiz edilerek elde edilen sonuçlar değerlendirilmiştir.

\section{Bulgular}

Araştırma alanında, zararlı, hastalık ve yabancı otlarla mücadele yapılmasına karşın ürün kaybı, Ayaş ilçesinde toplam \%25,92, Nallıhan ilçesinde ise toplam $\% 27,51$ olarak belirlenmiştir. Bu kayıpları detaylandıracak olursak;

Ayaş ilçesinde, fide döneminde meydana gelen ürün kaybı $\% 14,78$,tarla döneminde meydana gelen ürün kaybı \%5,99, hasat döneminde meydana gelen kayıp ise $\% 5,15$ olarak tespit edilmiştir. Hasat döneminde meydana gelen kaybın \%3,79'u meyve çatlaması, \%1,36'sı ise meyve çürümesinden dolayı meydana gelmiştir.

Nallıhan ilçesinde, fide döneminde meydana gelen ürün kaybı \%12,76, tarla döneminde meydana gelen ürün kaybı \%4,92, hasat döneminde meydana gelen kayıp ise $\% 9,83$ olarak tespit edilmiştir. Hasat döneminde meydana gelen kaybın \%4,44'ü meyve çatlaması, \%2,9'u meyve çürümesi, \%2,49'u ise güneş yanıklığından dolayı meydana gelmiştir.

Mücadele işlemlerinin yürütülmesine karşın meydana gelen ürün kayıplarının bitki koruma açısından başlıca nedenleri olarak aşağıdaki hususlar tespit edilmiştir:

Yürütülen anket çalışmaları sonucunda üreticilerin yaklaşık \%89'unun ilkokul mezunu olduğu belirlenmiştir. Eğitim durumu ile ilgili olarak şu gözlemimize yer vermenin durumun daha iyi anlaşılabilmesi bakımından faydalı olabileceği düşüncesindeyiz. Akkaya köyünde üreticilerin domates tohumlarını normal duvar boyası ile boyadıkları belirlenmiştir. Normalde üreticilerin almış oldukları domates tohumları ilaçlanmış olup, bu durumun herhangi bir karışıklığa neden olmaması için tohumlar özel olarak renklendirilmektedir. $\mathrm{Bu}$ renk maddesinin tohumun çimlenmesi ve gelişmesi üzerine herhangi bir olumsuz etkisi bulunmamaktadır. Ancak üreticiler ellerinde bulunan tohumları hastalık kaynaklarından koruyabilmek amacı ile boyamışlar ve bu boyalı tohumlarında çürüyerek elden çıktığı gözlemlenmiştir. Bu gibi arzu edilmeyen durumların önlenebilmesi açısından, üreticilerin eğitim düzeylerinin yükselmesinin nedenli önemli olduğu bir kez daha anlaşılmıştır.

Belirlenen ürün kayıplarının önemli bir bölümünün fide döneminde meydana geldiği görülmektedir. Üreticilerin \%56' sının fidelik toprağa herhangi bir işlem yapmadığı görülmüş, bu üreticilerin $\% 72$ ' si 100 adet tohumdan 75 adetten daha fazla fide elde ettiğini, \%28' inin ise 100 adet tohumdan sadece 50 ila 75 arasında fide elde ettiğini bildirmişlerdir. 2001 yılı itibarı ile 1 kilo külçe altın 13.500 YTL iken, 1 kilogram hibrit domates tohumu 20.000 YTL'dir (Ellialtıoğlu,2001). Bu yüzden öncelikle domates tohumları yörede sera olarak tabir edilen örtü altında hazırlanan fideliklere ekilerek yetiştirilmeye başlanmaktadır. Bu aşamada yapılan sörvey sırasında üreticilerin bu toprakları sterilize etmedikleri, zaman zaman Bolu 
Yeniçağ'dan torf getirttikleri, zaman zamanda kendi köyleri civarındaki yerlerden toprak alarak fide yastıklarını hazırladıkları belirlenmiştir. Yine aynı şekilde fide üretiminde kullandıkları materyalleri de herhangi bir sterilizasyon işlemine tabi tutmadıkları gözlenmiştir. Bu durum özellikle toprak kökenli hastalıklar için enfeksiyon kaynağı niteliğindedir. Nitekim bazı seralarda çok fazla miktarda solgunluk belirtilerine rastlanılmıştır. Yine seralarda havalandırma işleminin gereği gibi yapılmadığı anlaşılmıştır. Bu durumda sera içerisindeki nem oranı yükselmekte ve birçok hastalığın gelişimi açısından uygun bir ortam oluşturmaktadır. Ayrıca sırık domatesin yetiştiriciliğinde kullanılan fide çubuklarının da herhangi bir sterilizasyona tabi tutulmadığı gözlenmiştir. Bazı yerlerde iyi bir toprak hazırığı yapılmadığı da dikkati çekmiştir.

Tarla döneminde Nallıhan ilçesinde \%4,92, Ayaş ilçesinde ise \%5,99' luk bir ürün kaybının meydana geldiği belirlenmiştir. Üreticilerin $\% 66,67$ 'sinin sadece 1 defa üst üste aynı ürünü ektiğini bildirmesine karşın, \%5,56' sının 2 defa, \%11,11' inin 3 defa, \%11,11' inin ise 4 veya daha fazla üst üste ektiğini bildirmiştir. Geriye kalan \%6' sının ise tarlayı kiraladığı için, tarlaya üst üste kaç yıl aynı ürünün ekildiği hakkında bir bilgisi olmadığı tespit edilmiştir. Domateslerde toprak kökenli hastalıklar üst üste ekim yapıldığında toprakta yoğunluk kazanmaktadır. Bu yüzden hastalık görülen tarlalarda münavebe yapmak, patojenin toprakta yoğunluğunun azaltımasında etkili bir mücadele yöntemi olarak kullanılabilmektedir.

Bölgedeki üreticilerin $\% 55.56$ 'sı domates üretimini kısıtlayan ana faktörün hastalık, zararlı ve yabancı otlar olduğunu bildirmişler, kalan \%16,67'si ürünün pazarlamasının, \%27.78'i ise sulama ve tohumluk maliyetinin üretimi kısıtlayan ana faktör olduğunu düşünmektedirler. Üreticilerin mücadele yöntemleri konusunda daha bilinçli davranmaları gerekliliği, bu soruya vermiş oldukları cevap ile bir kez daha ortaya çıkmıştır.

Hastalık ve zararlıların teşhislerinin doğru yapılamadığı için yanlış ilaç seçimi ve kullanımı söz konusu olabilmektedir. Üreticilerin \%55.56' sı tarlada görülen böceklerin zararlı veya faydalı olduğu hakkında bir bilgisi olmadığını belirtmişlerdir. Yapılan görüşmelerde üreticilerin bir kısmının hastalık ve zararlıların teşhisini kendilerinin yaptığını, bir kısmının ise komşusuna danıştığı bir kısmının ise bayiler ve teknik elemanlardan yardım aldıklarını belirtmişlerdir.

Üreticiler hastalık ve zararlılarla mücadeleyi zamanında gerçekleştirememektedirler. Domates üretimi sırasında çiftçilerin \%50'sinin ilaçlama zamanı hakkında bilgiyi tarım ilçe müdürlüklerinden, \%22' sinin ilaç bayilerinden öğrendiklerini, \%28' i ise ilaçlama zamanın belirlerken kimseye danışmadıklarını bildirmişlerdir $\mathrm{Bu}$ nedenle de ilaçlardan beklenen etkiyi sağlayamamaktadırlar. Birbirlerine yakın yerlerde bulunan üreticilerin hepsi aynı zamanda mücadele işlemlerini gerçekleştirmedikleri için mücadele yapılmayan tarlalardan diğer tarlalara hastalık ve zararlıların bulaşma durumları ortaya çıkmakta ve bu durumda mücadeleden beklenen başarıyı azaltmaktadır.
Kullandıkları ilaçları seçerken üreticilerin \%44' ünün Tarım İlçe Müdürlüklerine danıştıklarını, \%22‘ sinin ilaç bayilerinin tavsiyelerini dinledikleri, \%11' inin hem ilaç bayilerini hem de Tarım İlçe Müdürlüklerini, yine \%11' inin hem tarım İlçe Müdürlükleri hem de diğer çiftçileri dikkate aldıkları, \%6'sının ilaçların hem ilaç bayileri hem de kendileri tarafından seçildiğini, kalan $\% 6$ ' sının ise ziraat odası tarafından yapılan tavsiyelere uydukları belirlenmiştir.

Üreticilerin \%16,67'si bir domates üretim dönemi içerisinde 5 defa, $\% 55,56$ ' sı 4 defa , \%22,22' si 3 defa, $\% 5,55$ 'i ise 1 defa ilaçlama yaptığını bildirmiştir. Görüldüğü üzere yapılan ilaçlamalarda da gereklilikten çok, gelişi güzel davranıldığı ortaya çıkmaktadır.

Üreticilerin hastalık ve zararlılara karşı kullanılan birkaç ilacı karıştırarak attıkları gözlenmiştir. Nitekim yapılan anket neticesinde üreticilerin \%88.88'i ilaçları kullanırken birbirleriyle ya da yaprak gübresi vb. maddelerle karıştırdıklarını bildirmişlerdir. Ancak bu üreticilerin sadece \%25' i tavsiye edildiği takdirde ilaçları karıştırarak kullandıklarını belirtmişlerdir. Bu durumda bitkilerde fitotoksik etkilerin gözlenmesi olası bir hale gelmektedir. Yine üreticilerden elde edilen bilgiler neticesinde zaman zaman aynı hastalık ya da zararlıya etkili olabilen birden fazla ilacı karıştırarak kullandıkları belirlenmiştir. $\mathrm{Bu}$ durumda da mücadele masrafları artmaktadır. Ayrıca, fide döneminde yapılan sörveyler sırasında böyle bir durumla karşılaşılmıştır. Akkaya köyünde üreticilerin fazla dozda ilaç kullanmaları nedeni ile fidelerde fitotoksik belirtilere rastlanılmıştır.

İlaç uygulamalarında doz ayarlamalarını üreticilerin bazıları ilaç etiketlerine göre bazıları ise kendi tecrübelerine dayanarak yapmakta olduklarını belirtmişlerdir. Bu durumda eksik doz ya da doz aşımı gibi istenmeyen durumlarla da karşılaşılmaktadır. İlaç uygulamalarının gerçekleştirilmesi sırasında da aynı durumların geçerli olduğu anlaşıımıştır. Hedef alınan zararlı etmenlerin ilaçlarla yeterince temas etmemeleri söz konusu olabilmektedir. Son ilaçlama ile hasat arasında geçmesi gereken sürelere özellikle dikkat edilmesi gerekmektedir. Bu konu insan sağlığı açısından son derece önemli bir konu olup, verilen sürelere titizlikle uyulması gerekmektedir. Özellikle domates gibi sık hasat işlemlerinin gerçekleştirildiği ürünlerde bu konu daha büyük önem kazanmaktadır. Bu konuda üreticilerin daha bilinçli hareket etmeleri gerekmektedir.

Boş ilaç ambalajlarının imhası konusunda ise üreticilerin gelişi güzel hareket ettikleri anlaşılmıştır. Üreticilerin \%55,56' sının ilaç ambalajlarını toprağa gömdüğünü, \%22,22' sinin yaktığını bildirmelerine karşın, $\% 11,11^{\prime}$ inin dere ve akarsulara attıklarını, \%5,56' sının çöpe attığını ve \%5,56' sının ise ambalajları yıkayıp tekrar kullandığı belirlenmiştir.

Yapılan sörvey sırasında hasat sonrasında tarlada bulunan bitkilerin olduğu gibi bırakıldıkları gözlenmiştir. Nitekim üreticilerin \%56'sı, üretim dönemi sonunda tarlasından domates bitki artıklarını sökmediğini ve tarlada bıraktıklarını bildirmişlerdir. Hastalık ve zararlılar açısından bu durum arzu edilmeyen bir husustur. Çünkü bu bitkiler, 
uygulamaları"

bu etmenlerin bir sonraki yılda enfeksiyon kaynağını teşkil etmektedir. Bunun sonucunda da bir sonraki yılda yöredeki üretici şikayetleri artarak devam etmektedir. Ancak bunun nedeni kendi yapmış oldukları hatalı işlemlerde yatmaktadır. Hasat artıklarının tarladan kesinlikle uzaklaştırılması gerekmektedir.

İlaçlama esnasında çiftçilerin \%67' sinin herhangi bir koruyucu elbise, maske, çizme vb koruyucu araç gereç kullanmadığı belirlenmiştir. Üreticilerin \%61' inin zirai ilaç kullandıkları sırada hiç zehirlenmediklerini bildirmelerine karşın, \%83' ünün ilaçlamalardan sonra gözlerde yanma, kaşıntı baş dönmesi ve bulantı gibi belirtiler hissettiklerini, \%6' sının bayıldığını belirtmesine karşın, sadece \%11' i herhangi bir belirti hissetmediğini bildirmiştir.

Hasat dönemi içerisinde Ayaş ilçesinde toplam $\% 5,15$, Nallıhan ilçesinde ise $\% 9,83^{\prime}$ lük bir ürün kaybının meydana geldiği ortaya konulmuştur. Üretim sezonunun başlamasından itibaren büyük çabalar sonucu hasat dönemine getirilen ürünlerde bu kadar kaybın meydana gelmesi gerçekten çok üzücüdür. Bu da üreticilerin sadece domatesi hasat olgunluğuna getirip bırakmanın yeterli olmadığını, hasat ve hasat sonrasında da gerekli tedbirlerin alınarak hiç değilse bu kayıpların minimuma indirilmesi veya tamamen ortadan kaldırılması için bilgilendirilmesi gerektiğini ortaya çıkarmıştır.

Ayaş ilçesinde fide döneminde, ilaçlama maliyetinin birim alana düşen toplam değişen masraflar içerisindeki payı \%3,30, tarla döneminde ise $\% 2,09$ olarak bulunmuştur. Nallıhan ilçesinde fide döneminde, ilaçlama maliyetinin birim alana düşen toplam değişen masraflar içerisindeki payı $\% 1,31$, tarla döneminde ise $\% 2,54$ olarak bulunmuştur. Üretim dönemi bir bütün olarak ele alınacak olursa Ayaş ilçesi için, ilaçlama maliyetinin birim alana düşen toplam değişen masraflar içerisindeki payı $\% 5,39$ ve toplam masraflar içerisindeki payı \%4.96 (fide döneminde $\% 3,15$, tarla döneminde $\% 1,81$ ), Nallıhan ilçesi için ise, ilaçlama maliyetinin birim alana düşen toplam değişen masraflar içerisindeki payı \%3,85, toplam masraflar içerisindeki payı ise \%3,56 (fide döneminde $\% 1,21$, tarla döneminde $\% 2,35$ ) olarak tespit edilmiştir. Elde edilen bu sonuçların en önemli özelliklerinden bir mücadele giderlerinin toplam masraflar içerisindeki payının göreli olarak düşük düzeyde olmasıdır.

Ayaş ilçesinde fide yetiştiriciliği sırasında üreticilerin hastalık etmenlerine karşı Champion (bakır hidroksit), Proplant (propamocarb-hidroksit), Antracol (propineb), zaralılara karşı ise Dursban 4 (chlorpyrifos-ethyl) kullandıkları belirlenmiştir. Ancak Proplant domateslerde mildiyö hastalığına karşı ruhsatlı olup domates mildiyösüne karşı ilaçlamaya günlük ortalama sıcaklığın $16{ }^{\circ} \mathrm{C}$ ve orantılı nemin $\% 80$ düzeyinde olduğunda başlanması gereklidir. Yada en pratik yöntem olarak domates yapraklarında 3-5 mm çaplı kahverengi lekelerin ve bunların alt yüzeyinde beyaz kül görünümünde küf tabakasının görülmesi ile başlanması gereklidir. Domates mildiyösü tarla koşullarında zarar oluşturduğu için fidelikte bu hastalıkla mücadeleye başlanmasına gerek bulunmamaktadır. Dolayısıyla fidelikte Proplant kullanımına gerek yoktur. Domateslerde fidelikte en büyük problem fide kök çürüklükleridir. Bu hastalığa karşı
Antracol kullanımı yerinde bir uygulamadır (Anonymous 1995). Aynı ilçede fidelerin tarlaya aktarıldıktan sonra üreticilerin hastalık etmenlerine karşı Champion (bakır hidroksit), Antracol (propineb), Tri-Miltox Forte (bakır tuzları+mancozeb), zararlılara karşı Confidor (imidacloprid), İmparator (cypermethrin), Decis (deltamethrin), Karate (lambda-cyhalothrin), Agro DDVP (dichlorvos), Dursban 4 (chlorpyrifos-ethyl), Anthio 33 (formothion), Meteor (fenpyroximate) ve Comite (propargite), yabancı otlara karşı ise Sencor (metribuzin), Treflan (trifluralin) ve Total (glyphosare isopropylamine) kullandıkları belirlenmiştir. Yabancı ot ilaçlarından Total ülkemizde sebze ekiliş alanlarında ruhsatlı değildir (Yücer 2000).

Nallıhan ilçesinde fide yetiştiriciliğinde üreticilerin hastalık etmenlerine karşı Antracol (propineb), Benlate (benomyl), Ridomil MZ (metalaxyl+mancozeb), Pomarsol (thiram), Captan (Captan), Tri-Miltox Forte (Bakır tuzları +mancozeb) zaralılara karşı Decis (deltamethrin), Karate (lambda-cyhalothrin), İmparator (cypermethrin), kullandıkları belirlenmiştir. Ancak Ridomil daha önce Ayaş ilçesinde fide döneminde kullanılan Proplant ta olduğu gibi domateslerde mildiyö hastalığına ruhsatlı olmasına karşın fide döneminde bu hastalıkla mücadeleye başlanmasına gerek bulunmamaktadır. Dolayısıyla fidelikte Ridomil kullanımına gerek yoktur (Anonymous 1995).

Aynı ilçede fidelerin tarlaya şaşırtılmasından sonra hastalık etmenlerine karşı Antracol (propineb), Tri-Miltox Forte (bakır tuzları+mancozeb), Trival Forte (bakır tuzları+mancozeb), Dikozeb (mancozeb), Benlate (benomyl) ve Göztaşı, zararlılara karşı Confidor (imidacloprid), İmparator (cypermethrin), Decis (deltamethrin), Karate (lambda-cyhalothrin), Dursban 4 (chlorpyrifos-ethyl), Ches (pymetrozine) Arrivo (cypermethrin), Nurelle (cypermethrin), Hezudin (diazinon), Totem (fenazaquin), Terramon (methamidophos) ve Nissuron (hexithiazox), yabancı otlara karşı ise Sencor (metribuzin) kullandıkları belirlenmiştir. Nissuron ülkemizde patlıcanda kırmızı örümceğe karşı ruhsatıdır ancak domateslerde ruhsatı değildir. Yine Terramon ise insektisit ve akarisit özelliğinde bir pestisit olup ülkemizde pamuk ve tütünlerde ruhsatı olup domateslerde ruhsatlı değildir (Yücer 2000).

\section{Tartışma ve Sonuç}

Araştırma alanı içerisinde yer alan Ayaş ve Nallıhan ilçelerinde bulunan domates üreticileri, gerek Ankara iline yakın olmaları, gerekse de ulaşım imkanlarının elverişli olması nedeniyle giderek daha yoğun domates yetiştiriciliğine yönelmektedirler.

Bilindiği üzere ürün kayıplarının nedenleri arasında sertifikasız tohum kullanımı, sulama, gübreleme, toprak işleme uygulamalarının yanı sıra hastalık ve zararlılarla mücadelede önemli bir yer tutmaktadır. Etkin ve bilinçli bir mücadele yapılmadığı zaman, diğer işlemler yeterli düzeyde de olsa, ürün kaybı önemli boyutlara ulaşabilmektedir. Bunun sonucunda, verim ve kalitedeki azalma neticesinde ürün maliyeti artmakta ve elde ettikleri kar oranı düşmektedir. 
Bu bölgedeki üreticilerin $\% 55,56$ ' sına göre domates üretimini kısıtlayan ana faktör hastalıklar, zararlılar ve yabancı otlardır. Hastalıklar, zararlılar ve yabancı otlar ile ilgili mücadele çalışmalarının yürütülmesine karşın Ayaş ilçesinde toplam \%25,92, Nallıhan ilçesinde ise toplam $\% 27.51$ 'lik bir ürün kaybı meydana gelmiştir. Elde edilen araştırma sonuçlarına göre, üreticiler tarımsal mücadele yöntemleri hakkında yeterli düzeyde bilgiye sahip olmadıkları için kimyasal mücadeleyi zamanında ve etkin bir biçimde uygulayamadıkları belirlenmiştir. Bu nedenle, meydana gelen ürün kaybı sonucu oldukça önemli ekonomik zararlar ortaya çıkmakta olup ürünlerdeki olası ilaç kalıntısı nedeniyle de sağlık bakımından olumsuz durumlarla karşı karşıya kalınabilmektedir. Üreticilerin son ilaçlama ile hasat arasında geçmesi gereken sürelere uymalarının insan sağlığı açısından ne kadar önemli olduğu konusunda aydınlatılması ve bu sürelere uymaları hususunda gerekli tedbirlerin alınmasına özen gösterilmelidir. Pestisit kalıntı analizlerinin yapılabilmes için gerekli olan alt yapının oluşturulması sağlanarak, faaliyete geçirilmesi gerekmektedir. Bilinçli ve etkin bir mücadele işleminin gerçekleştirilebilmesi için üreticilerin teknik elemanlarla olan diyalogunun geliştirilmesi bir zorunluluk olarak ortaya çıkmaktadır. Mücadele işlemleri daha bilinçli gerçekleştirilirse, mücadele masraflarında azalma sağlanabilecek ve üretim kaybı da daha az olabilecektir. Bütün bunların yanı sıra en önemli konulardan biri olan çevre ve insan sağlığı konusunda bitki koruma ilaçlarından dolayı kaynaklanabilecek olan problemler en az düzeye indirilebilecektir.

Elde edilen çalışma sonuçlarından da görülebileceği gibi bazı üreticilerin domateslerde ruhsatlı olmayan bazı tarım ilaçlarını kullandıkları belirlenmiştir. Bu durum hem domates üretimi hem de çevre ve insan sağlığı açısından büyük önem arz etmektedir. Üründe ruhsatı olmayan ilaçların kullanımından dolayı oluşabilecek tehlikelerin önlenebilmesi için, üreticilerin ilaçları seçerken teknik elemanların önerileri doğrultusunda hareket etmeleri gerekmektedir. Üreticilerin ilaç bayileri ile olan münasebetlerini de dikkate alarak, ilaç bayilerinde en azından konu uzmanı bir Ziraat Mühendisinin bulundurulması sağlanmalıdır.

Üreticilerin kendi yapmış oldukları hatalı uygulamalar sonucunda meydana gelen ürün kayıplarının engellenmesi için, üreticilerin ilgili tarım kuruluşları ve üretici örgütleri tarafından eğitilmeleri ve bilgilendirilmeleri oldukça yararlı olacaktır. Yapılan anket neticesinde üreticilerin \%83.34' ü entegre zararlı yönetimi ve organik tarım terimlerini daha önce duymadıklarını belirtmişlerdir. Bu eğitimlerde özellikle entegre mücadele konusuna ağırlık verilerek daha bilinçli mücadele uygulamalarının gerçekleştirilmesine katkıda bulunulmalıdır.

Zararlılarla savaşımda dikkate alınması gereken önemli noktalardan biri de zararlının "Ekonomik Zarar Düzeyi ve Ekonomik Zarar Eşiği"dir. "Ekonomik Zarar Düzeyi", zararlının gerçekten ekonomik bir zarara neden olan en düşük populasyon düzeyini gösterir ve ancak bu düzeyde bir mücadele gereklidir. "Ekonomik Zarar Eşiği" ise artan populasyon karşısında, zarar yapacak düzeye ulaşmadan populasyonu düşürme girişimlerinin gerekli olduğu düzeydir. Zararlı ile mücadeleye populasyon düzeyi ekonomik zarar eşiğine ulaştığında mutlaka başlanmalıdır (Kansu 1986).

Önceleri zararlılarla savaşımda kullanılan metotlar, zararının hayat çemberine ait biyolojik bilgilerine dayandırılmış ve zararlının en zayıf noktalarına yöneltilmiştir. Ancak daha sonraları, gelecekteki populasyon durumunu tahmin etme ve savaşım uygulamalarının gerçekten gerekli olup olmadığının karşılaştırılmasında, zararlı ve faydalı faunanın birlikte ele alınması ve bunların birlikte bilinmesinin önemi dikkate alınmıştır. Böylece ana zararlı populasyonu incelenirken doğal düşmanlarının da aynı ortamda populasyon durumlarının incelenmesi gerekir.

Entegre Zararlı Yönetiminde işlemler, türlerin ekosistemden tamamen elimine edilmesi değil, zararııın ekonomik zarar meydana getirmeyecek düzeyde dengede tutulması için uygulanmaktadır. Ortamda mevcut ve zararlı olabilme kapasitesindeki bir organizmanın bulunuşunun mutlaka zararlı problemini ortaya koymayacağının anlaşılması gerekir. Bu ekonomik zarar seviyesinin bilinmesini gerektirmektedir. Burada bir savaşım tekniğinin seçilebilecek bir diğer savaşım tekniğine ters düşmemesi önemlidir. Entegre Zararlı Yönetim sistemleri ile zararlının yönetimi kararının verildiği sırada sadece zararlı organizmayı değil, tüm ekosistemi dikkate almak gerekmektedir. Kimyasal savaşıma karar verilmesi durumunda kullanılacak ilaçlar mümkün olduğu kadar etki spektrumu dar ve hatta selektif olmalıdırlar (Toros ve Maden 1991 )

Pestisitlerin çevreye verdikleri zararların en alt düzeylere indirilebilmesi için kullanılacak aletler iyi seçilmeli, kalibrasyonları yapılmalı ve ilaçlama dozu ilaç etiketlerine göre ayarlanmalıdır. İlaçlama sonrası boş ambalajların gereği gibi imhası konusunda üreticilerin mutlaka bilinçlendirilmeleri gerekmektedir.

$\mathrm{Bu}$ konu üzerine bundan sonra yapılması planlanan araştırmaların, ilaçlı ve ilaçsız uygulamaların yer aldığı tarla denemeleri ile, yapılacak olan anket çalışmaları sonuçlarının birlikte değerlendirileceği çalışmalar şeklinde olması daha yararı sonuçlar verebilecektir. Bu tip araştırmaların bu çalışmada olduğu gibi ilgili farklı disiplinlerin katılımı ile gerçekleştirilmesinin daha yararlı olacağı düşünülmektedir.

\section{Kaynaklar}

Abak, K., H.Y. Duşgan, ve N. Sarı. 2000. Güneydoğu Anadolu bölgesinde Domates Yetiştiriciliği. TÜBITAK, Türkiye Tarımsal Araştırma Projesi Yayınları, 25s. TÜBITAK Matbaası, Ankara.

Anonymous 1995. Zirai Mücadele Teknik Talimatları. Cilt 2, Cilt 4 T.C. Tarım ve Köyişleri Bakanlığı, Koruma Kontrol Genel Müdürlüğü, Ankara.

Anonymous1999. http://www.fao.org.

Bremer, H. 1948. Türkiye Fitopatolojisi. Güney matbaacılık ve Gazetecilik T.A.O., Ankara. 

uygulamaları"

Bremer, H. 1954. Türkiye Fitopatolojisi Cilt 3 Bahçe Kültürleri Hastalıkları. Çeviren: M. Özkan. Ziraat Vekaleti Neşriyat ve Haberleşme Müdürlüğü, Ankara İstiklal Matbaası 715 (295).

Dolar, S.M., N. Tekinel ve Y.Z. Nas. 1976. Tarsus Sulu Ziraat Araștırma Enstitüsü' nün Bölgeye Adapte Etmeye Çalışı̆̆ı Domates Çeşitlerinin Virus Hastalıklarına Dayanıklı Olanlarının Tespiti Üzerine Araştırmalar. Bitki Koruma Bülteni 16 (1): 27-32.

Ellialtıŏlu, S. 2001. Unihaber, Ankara Üniversitesi Haber Bülteni 12. Ankara Üniversitesi Basımevi.

Erkuş, A., S. Toros, ve Ö.F., Yalçın. 1992. Sincan ilçesi sebze üreticilerinin Zararlı ve Hastalıklara Karşı İlaç Kullanım Durumu ve İlaç Kullanımının Ekonomik Analizi üzerine bir araştırma, Tarım Ekonomisi derneği, Tarım Ekonomisi Dergisi 1 (59-66) İzmir.

Güldür, M.E. ve M.A., Yılmaz, 1995. GAP Bölgesi Bitki Koruma Sorunları ve Cözüm önerileri Sempozyumu. 27-29 Nisan 1995. 251-257, Şanlıurfa.

Güneş,T. ve Arıkan, R. 1988. Tarım Ekonomisi İstatistiği. A.Ü. Ziraat Fakültesi Yayınları 1049, Ders Kitabı: 305, Ankara.

Gürcan A. 1968. Orta Anadolu' nun Bazı İllerinde Yaprakları ve Meyveleri Yenilen Sebzelerde Zarar yapan Mantari Hastalıkların Türleri Yayılış Alanları, Zarar Şekilleri ve Geçiş Yolları Üzerine Araştırmalar. Ziraat Fakültesi Yayınları: 325 Bilimsel Araştırmalar ve İncelemeler 118 (90).

Kansu, İ.A. 1986. Genel Entomoloji. IV. Baskı. A.Ü. Ziraat Fakültesi Yayınları 965, Ders Kitabı: 283, Ankara.

Kahveci, E. ve A. Gürcan. 1993. Antalya ilinde domateslerdek bakteriyel hastalık etmenlerinin tespiti. Bitki Koruma Bülteni $33(3-4)$.

Karahan, O. 1960. Çukurova Bölgesi Domateslerinde Solgunluk Hastalı̆̆ı Amilinin (Fusarium) Türleri, Zarar Dereceleri ve Bu Hastalığa Mukavim Domates Varyetelerinin Tespiti Üzerine Çalışmalar. Ziraat Vekaleti Ankara Zirai Mücadele Enstitüsü Müdürlüğü, Sayı 13, Ayyıldız Matbaası, Ankara 1960.

Karahan, O. 1963. Sebzelerde Fide Kök Çürüklüğü hastalığı ve Mücadele Metodu Üzerine Çalışmalar. Tarım Bakanlığ Ankara Zirai Mücadele Enstitüsü Müdürlüğü Sayı 40. Ayyıldız Matbaası, Ankara 1963, 56 Sayfa.

Öngören, K., N. Kaya ve S Türkmen. 1975. Ege bölges sebzelerinde zarar yapan kırmızı örümcek türlerinin tesbiti, hakim tür olan Tetranychus urticae (Koch)' nin biyolojisi Mücadelesi ve doğal düşmanları üzerine araştırmalar. Bitk Koruma Bülteni 15 (2).
Özalp, M.O. ve M. Bağcı. 1968. Domates solgunluk hastalığı (Fusariose)' na mukavim çeşit tespiti üzerine çalışmalar. Bitki Koruma Bülteni 8 (4).

Şengonca, A. ve O. Yurdakul. 1977. Çukurova Bölgesinde Beyaz Sinek (Bemisia tabaci Genn.) salgınının Ekonomik Etkileri, Çukurova Üniv. Ziraat Fak. Yıllığı 6 (2).

Tanrıvermiş, H. 2000. Orta Sakarya Havzası'nda Domates Üretiminde Tarımsal İlaç Kullanımının Ekonomik Analizi . Tarımsal Ekonomi Araştırma Enstitüsü Yayınları. 42.

Tatıdil, F.F., T. Kıral, A. Güneş, K. Demir, E. Gündoğmuş, H. Fidan, F. Demirci, C. Erdoğan, ve D. Aktürk. 2003. Ankara Illinde Domateste Hasat Öncesi ve Hasat Sırasında Oluşan Ürün Kayıplarının Ekonomik Analizi. TÜBiTAK-Tarp 2387 nolu proje sonuç raporu 86 sayfa, Ankara.

Temiz, K. ve S. Fesli. 1978. Ege Bölgesinde Yetiştirilen Sebze Türlerine ait çeşitlerde tohumla geçen fungal hastalık etmenlerinin tespiti üzerine araştırmalar. TÜBITAK Yayınlar 397.

Toros, S. 1976. Bitki koruma İlaçlarının Çevre Sağlığına Olan Etkileri ve Öneriler . MPM verimlilik Dergisi 5 (4): 505-522.

Toros, S. ve S. Maden. 1991. Tarımsal Savaşım Yöntem ve İlaçları. II. Baskı. Ziraat Fakültesi Yayınları 122., Ders Kitabı 352. Ankara.

Yücel, S. 1989. Domates Fusarium Solgunluğuna (Fusarium oxysporum f.sp.lycopersici (Sacc.) Synd. And Hans.) Karşı Biyolojik Kontrolde Antagonizim ve Toprak Solarizasyon uygulamalarının Karşılıklı Etkileşiminden Yararlanma Olanakları Üzerine Araşırmalar. Adana Zirai Mücadele Araştırma Enstitüsü Müd. Araştırma Yayınları Serisi 64.

Yücel, S. 1994. Akdeniz Bölgesi Örtü Altı Sebze Alanlarında Görülen Fungal Hastalıklar. Bitki Koruma Bülteni 34 (1-23).

Yücel, S. ve A. Çınar. 1989. Domates Fusarium Solgunluğuna (Fusarium oxysporum f.sp.lycopersici (Sacc.) Synd. And Hans) karşı Biyolojik Kontrolde Antagonistlerin ve Toprak Solarizasyon Uygulamalarının Etkileri. Doğa. Turkish Journal of Agricultur and Forestry. Türkiye Tarım ve Ormancılık Dergisi 13: 1372-1393.

Yücer, M. M. 2000. Tarım İlaçları 2000, Hasad Yayıncılık Ltd. Şti., İstanbul.
İletişim Adresi:
Fikret DEMiRCi
Ankara Üniversitesi Ziraat Fakültesi
Bitki Koruma Bölümü - ANKARA
Tel : 0-312-5961119
e-mail: fdemirci@agri.ankara.edu.tr 